\title{
A Future Path of RBMS: A Bookseller's Point of View
}

Rare books, manuscripts, early ephemera, photographs, film—everything rare, scarce, hard to find, and perhaps even harder to preserve- is this the final frontier, or are we rehashing the same questions that have been around since the hand-press days: what to collect, the cost of materials to buy and preserve, and how to get people into and using special collection libraries? Do we view the material itself as the treasure or spend our time figuring out how to create and then use new technology to legitimize and even promote our own positions? Are library positions so narrowly focused that any interest in the words and images are left behind at the front door to the reading room?

Nearly sixty years ago, the Rare Book and Manuscript Section (RBMS) of the American Library Association was created "to promote wider understanding of the value of rare books to scholarly research and to cultural growth, [and] bring improvement to the care, use and recognition of rare books in all libraries." ${ }^{\prime}$ The interest was in fostering professional growth and camaraderie between members of a community that work with rare books and related materials. The RBMS preconference, in addition to its social aspects (always most appreciated), is a forum for providing information on the latest technology and discussing the profession, acting as a gathering place for those with similar interests.

But have we left behind the materials with which we work? Are we artists who are too involved with the art world, as opposed to the basic clay, paint, and canvas that allow our existence? Let's go back to basics and share what we have in common: the books and archival materials. These are the collective memory of our history, our culture. The stand that we have chosen to take in our professional lives rests upon this very foundation.

As a bookseller, my main focus is, of course, the books-where to find them, the tools of my research, and then where to sell them. We are, as Michael F. Suarez so

1. "Historical Sketch of RBMS," available online at http://rbms.info/about/index.shtml [accessed 11 March 2013]. 
deftly put it, "keepers of the archive,"2 the same as special collections librarians and archivists. Books pass through my hands on a long, sometimes half-a-millennium journey, to wind up on the shelves of collectors and, ultimately, special collection libraries. Booksellers have become the conduit between the collector and the library, either through sale or donation. The interests, indeed, of a bookseller and a special collections librarian are so much more similar than contradictory. We are an integral part of the process and, as such, should be an integral part of the Section. It is therefore fitting and proper that booksellers should also have an opinion about the future path of RBMS.

The 2012 San Diego preconference was one of the best I have attended in my twenty years of habituating RBMS meetings. A number of important topics and issues were repeatedly swatted around, including concerns about jobs and making the most of limited resources.

Many booksellers depend upon special collections libraries for their livelihoods. So we are, naturally, also concerned about those same issues: Jobs - that is, keeping them, ensuring their relevance, and the availability of prospects for graduates of library schools - and, certainly, budgets and how to make the most of existing resources. These issues facing libraries are just as sharp and real to booksellers.

Other issues that were discussed at the preconference included digitization (no fad, but an enduring component of our work), communication (between librarians, with booksellers, and between and with scholars and other users, including students), and of course outreach, the new order of the day for institutional collections.

The role of the bookseller in the RBMS context is of incredible importance. Our job is to know collections as well as the market. This intimate understanding can be advantageous to the long-term planning of any institutional special collections, especially considering efforts to focus on collection strengths. The basis of this knowledge is the relationships we form with librarians. That is why RBMS is so important. Librarians who have experience working with booksellers clearly see the mutual benefit in those relationships. And that is true whether or not the librarian is actively buying books.

Books and manuscripts, especially the rare ones, are expensive, for all of us. But I believe the community has overcome the notion that booksellers are out to ham-

2. Michael F. Suarez, Plenary Session III, Object: Book (1:38:35), FUTURES! The 53rd Annual RBMS Preconference, San Diego, Calif., June 22, 2012, available online at http://rbms.info/ conferences/preconfdocs/2012/Talks/2012_plenary_closing.mp3 [accessed 11 March 2013]. 
mer the libraries for as much money as possible. It isn't about the money! Honestly! For those of us who regularly deal with institutional collections around the country and around the world, it is more akin to adoption, making certain our books wind up in the best possible place, where they can be used for scholarly research.

The future of RBMS is thoroughly tied to the future of bookselling, as well as the future of special collections libraries. We will very likely be discussing the same, or very similar, topics as we did at the San Diego preconference. We know that scholars will continue to use special collections materials to do research. What those materials will be, what they will look like, and how the libraries will provide access to those materials: all are questions about which we can only speculate.

We share the experience of accepting, learning, and using new technology to access, acquire, and distribute materials with librarians, because we are both affected by evolving technology. As it becomes available and common, so will we move ahead to use it in buying and selling books. We will not be displaced by technology. Rather, we will embrace it because our focus will not change: expanding collections where possible, by purchase or donation, with a greater awareness of the location of material to provide access. We maintain the moral link between ourselves and our constituents, supplying the goods, setting up the ability to dispense our knowledge.

Librarians are dedicated people who care about the service they provide. My sense is that very few look upon their work as merely a job. They are and always have been courageous in the defense of freedom from censorship and the right of the people to have access to knowledge.

Bookselling today is a world affair. It calls for imagination and courage. But we need to be trained in the techniques and ways of thinking of librarians. As booksellers, our job is to supply the needs of the special collections libraries. To a great extent, we remind librarians of the very reason for their being librarians, that books are valuable and influential.

We can both cultivate book collectors to our common good. Books, one of our great sources of knowledge, all of the priceless treasures of the past, have survived mostly because of the collector who has had the dream and spent the money for their acquisition and preservation. Because of shrinking institutional budgets for rare books, a greater percentage of the dollars spent buying rare books will come from private collectors.

These days, it tends to be difficult to keep an optimistic attitude about the rare book and manuscript business. We have seen the significant decline of bookstores 
and heard the dire predictions of the beginning of the end of the book. Good material is scarce, and new collectors even more so. To a great extent, students in the middle and high schools, many of whom are never introduced to a library, are certain that, if information is not online, it does not exist, at least in the microcosm of personal experience. But I have not seen a decline in the passion that both booksellers and special collections librarians bring to our work. I have found a great strength in our shared goals and a willingness to be flexible for the benefit of those goals. Librarians and archivists want their materials used. More librarians are thinking outside the box with respect to access and outreach — they no longer sit back and wait for classes to come into the reading room. They are proactive and creative when it comes to sharing library collections and materials. Booksellers want to and will continue to supply those materials. The future will reveal the extraordinary ability of ours to further develop and handle the evolution of that cycle of supply and access, and it will be based upon our relationships and our ability to communicate. As an organization, RBMS looks to promote the interests of its members, especially with respect to continuing education and professional growth opportunities. Booksellers have always, necessarily, been involved in the life of the rare book. Even if all books ultimately go to institutional collections, the journey before that point intimately involves the bookseller. We embrace the relationship with the library and librarian, seeking to create and maintain a support structure. Our involvement with RBMS, therefore, is critical.

Antiquarian books, and those of us who revel in them for our livelihoods, are connected, both to the past and the present. Our combined job is to kindle (sorry) an awareness of the knowledge, the story, the past presenting itself, to ourselves, collectors, researchers, and everyone who just may be interested. While the technology may change, the mission to enrich our communities remains our ultimate challenge, one we share on a daily basis.

As Jake Zeitlin said, "There can never be too many libraries or too many bookshops. They are both to a considerable degree the measure of the cultural level of a community and of a society." 